\title{
COVID-19 and Adaptation Strategies in Community-Based Tourism: Insights from Community-Based Tourism Sector in Central Java
}

\author{
Retna Hanani ${ }^{1 *}$, Amni Zarkasyi Rahman ${ }^{2}$, and Yuliana Kristanto ${ }^{3}$ \\ ${ }^{123}$ Public Administration Department, Faculty of Social and Political Science, Universitas Diponegoro
}

\begin{abstract}
High positivity rate of COVID-19 in Indonesia leads to the creation of government policies to limit human mobility. One of the sectors most affected by these policies is the tourism sector. In 2019, tourism sector contributed approximately US\$ 15 billion. However, income from this sector has fallen by up to $90 \%$ due to the sharp decrease of tourist arrivals during the pandemic. One of the tourism sectors that has experienced a significant impact due to COVID-19 is community based tourism especially water-based tourism. This study examines adaptation policies taken by the community-based tourism sector, namely Umbul Ponggok and Tawangmangu in response to the pandemic. In this research, we adopt the IPCC definition of climate adaptation. IPCC defines adaptation as special acts, systematic change, as well as institutional reform induced by the volatility of climate. We are particularly interested in how community-based tourism sector restructures and reorganizes its operation and how they mobilises local community to support its adaptation policies. We conclude that, similar to Tompkins and Adger (2004) account on adaptation policy, adaptive capacity can vary between regions and even households. Therefore, adaptation policies require strategies and management approaches that are flexible and inclusive and consider the varied characters of communities and individuals. Keywords: Adaptation, COVID-19, community-based tourism
\end{abstract}

\section{Introduction}

The Indonesian government issued various policies in order to limit the widespread of COVID-19 in Indonesian territory. Various regulations issued by the Indonesian government include the obligation to wear a mask every time you leave the house, work from home, school from home, implement physical distancing, several quarantine areas, a limit mobilization that occurs in the community, the closure of various kinds of public places, and the imposition of large-scale social restrictions (PSBB) 1.

On the one hand, these policies need to be implemented, but these policies also impact people's lives. Various community economic activities have been forced to close to support government policies in minimizing the spread of the covid-19 virus. The most impacted

\footnotetext{
*Corresponding author: r.hanani@live.undip.ac.id
} 
economic activity is the tourism sector2. All activities related to the tourism sector, such as recreation areas, various shopping centres, shops, and markets, have decided to temporarily close to minimize the spread of COVID-19. One of the indicators of the impact of COVID19 on tourism sector can be seen in the decline of international tourists visiting Indonesia in 2020 (Table. 1)

Table 1. Number of International Tourists visiting Indonesia.

\begin{tabular}{|c|c|c|}
\hline No & Year & International Tourists visiting Indonesia \\
\hline 1 & 2017 & 14,04 million \\
\hline 2 & 2018 & 15,81 million \\
\hline 3 & 2019 & 16,11 million \\
\hline 4 & 2020 & 4.05 million \\
\hline
\end{tabular}

Source: Badan Pusat Statistik, 2021

According to World Tourism Organization standards, the Indonesian government tries to save the tourism sector by implementing tourism crisis mitigation policies. The Ministry of Tourism and Creative Economics of the Republic of Indonesia adopted World Tourism Organization standards according to Indonesian tourism. The management of crisis mitigation in the tourism sector is divided into three stages, namely the "emergency response" stage (March-29 May 2020), the "recovery" stage (June-December 2020) and the "normalization" stage (January-December 2021). According to this stage, Indonesia is currently entering the recovery stage into the normalization stage. One indication of this stage is the implementation of health protocols for every recreation area or tourist destination from the national level to the tourism village level in Indonesia by the Decree of the Minister of Health of the Republic of Indonesia Number HK.01.07/ MENKES /382/2020.

The government has also budgeted IDR 14.4 trillion in the 2021 State Budget (APBN) to save tourism. The government uses this budget to continue the development of tourist destinations by developing various attractions, accessibility and amenities to attract domestic and international tourists. The government also increases the promotion and participation of private business actors.

Although the government has attempted to provide incentives to revive the tourism sector, in 2021, the Central Java Provincial Government, through the Central Java Provincial Youth, Sports and Tourism Office, decided not to target the number of tourist visits this year. The main focus of the Central Java provincial government is to increase awareness and services in implementing health protocols in the tourism sector.

In this paper, we examine to what extent community-based tourism, in the form of tourism village (Desa Wisata), implemented adaptation policies during the COVID-19 pandemic. Tourism village is one of the government programs to boost economic growth in rural areas and protect the environment. Through desa wisata program, the village government generates additional income and, at the same time, protects the environment. This article focuses on the water-based tourism sector as this sector is most affected by the pandemic. This study specifically examined Umbul Ponggok and Tawangmangu to illustrate the impact and adaptation policies undertaken by community-based tourist attractions in Central Java. Umbul Ponggok is located in Ponggok Village, Polanharjo District, Klaten Regency, Central Java. The COVID-19 pandemic resulted in the loss of Umbul Ponggok's potential income of IDR 14 billion. In addition to the loss of potential income, the potential development plan for Umbul Ponggok to attract visitors has been delayed due to the COVID-19 pandemic. Before the pandemic, the manager of Umbul Ponggok had set an income target of up to IDR 21 billion throughout 2020 .

\section{Method}


This research was conducted using a qualitative approach to explore various policies and adaptive measures the community-based tourism sector took in responding to the impact of the COVID-19 pandemic3. In this article, we specifically discuss aspects of adaptation policy based on the experiences of policymakers and policy implementers. The total number of informants we interviewed was seven key figures. The informants in this study were the Tourism Office of Central Java Province $(n=1)$, the Tourism Office of Klaten Regency $(n=$ 1), the Tourism Office of Karanganyar Regency $(n=1)$, the manager of Umbul Ponggok ( $n$ $=2)$, the tourism manager of Tawangmangu $(n=2)$.

\subsection{Theoretical Framework}

Preliminary Preliminary research on adaptation suggests that adaptation can be conceptually defined as specific actions (for example, a farmer shifting from one crop to another more suited to environmental changes), systematic change (for example, diversifying rural livelihoods), or institutional reform (reviewing water and land tenure reform)4. Adaptation can be both a product and a process5. Adaptation becomes a process, which includes learning about risks, evaluating response options, creating conditions that enhance adaptation, mobilizing resources, implementing adaptations, and reviewing options with new learning.

Adaptation occurs at a different but related level. Policies shaped by national and international circumstances set goals to be achieved at the local and regional levels. Individuals and organizations, however, do not operate separately. The interpretation of information and its translation into decisions and behaviour is influenced by the social context, individual characteristics, and direct experience. In other words, adaptation is a multi-scalar process of multilevel governance, concerned with the interaction of individual and collective behaviours that act from the bottom up and from the top down in response to changing circumstances.

Adaptation can be implemented by a group of actors that can be generally divided into three main domains: national and subnational government (state actor domain), private sector (market actor domain), and community (social actor domain)7. Through special bridging arrangements, actors interact, combine, and mobilize collective action that seeks to overcome actor weaknesses while exploring the strengths of other actors. Further, communities and comanagement organizations dealing with disasters frequently have systems to improve social and ecological resilience. Changes in the environment require mechanisms and new institutions to create community resilience. A group effort constructing the growth of the community's resilience depends on the quality of network and engagement that facilitate this type of learning-based management8. Drawing from the previous literature on policy adaptation, this article tries to look at how adaptation policy that usually focuses on natural disaster governance could be implemented during the COVID-19 pandemi.

\section{Findings and Discussion}

\subsection{Government policy}

The Pandemic COVID-19 came when the Central Java Provincial Government was trying to boost the development of the tourism sector by developing its potential and providing tourism infrastructure. Until 2018 Central Java had 612 travel attractions consisting of 212 (Naturebased attraction), 127 (Tourism and Culture), 170 (artificial destination), 31 (Special Interest destination), 72 other forms of travel destination, and 353 Tourism Villages9. The widespread impact of the COVID-19 pandemic has made the Central Java Provincial Government issue several policies that emphasize the strict implementation of health 
protocols with possible sanctions for the closure of locations. From this policy, throughout 2020, as many as 20 tourist destinations in Central Java Province were forced to close or stop operating permanently due to the impact of the COVID-19 pandemic.

Central Java Provincial Tourism Office reveals that since October 2020, travel destinations are welcome to receive tourists. Even so, the health protocol is still an important requirement that must be met. To reduce the risk of the spread of COVID-19, the Central Java Provincial Tourism Office also closed access to foreign tourist visits. Central Java Provincial Tourism Office travellers prioritize internal tourists from inside Central Java (internal province). For outside the province (external tourists), the government restricts the number of tourists and reduces operating hours.

In addition to the Central Java Provincial Tourism Office policies, the Klaten District Government's Tourism and Youth Culture Office team has also carried out various restrictive policies such as making unannounced visits to tourist objects, including tourist villages in Klaten Regency. According to the Klaten Regency Tourism Office, this effort is part of the evaluation. Apart from evaluating by inspection, the Klaten Regency Tourism Office wants to conduct random swab tests regularly on all tourist objects. However, the Klaten Regency Tourism Office admits that they are experiencing financial constraints. One of these random evaluation policy results was the closure of Umbul Ponggok and Umbul Pelem in Klaten, which were closed again after two people were confirmed positive for COVID-19. It was based on the results of the swab during joint leave.

In contrast to the policy of the Klaten Regency, The Tourism, Youth and Sports Office of Karanganyar Regency said that there was no closure of tourist attractions in Karanganyar during the Covid 19 pandemic. One of the reasons is that during the COVID-19 pandemic, coupled with the Enactment of Restrictions on Community Activities (PPKM), the impact was hefty on tourism business actors. The number of visits to each tourist spot in Karanganyar Regency, especially Ngargoyoso and Tawangmangu Districts, is arguably very few or almost non-existent. "The visitors are very minimal. There are at most two people, 20 people. Forty employees, only two visitors a day."

\subsection{Local Destinations' Adaptation Policies}

Managers of water tourism objects in Klaten are starting to welcome tourists following the permission of opening water tourism in October 2020. When the tourism objects reopen, tourism object managers must prepare facilities, including meeting health protocols.

The admission from the manager of Umbul Ponggok is as follows: "For health protocol facilities we are starting to prepare today. Such as hand washing stations, hand sanitisers, masks, appeals and so on". Preparations for implementing the health protocol were carried out for seven months when Umbul Ponggok was closed. During the closure, the manager of Umbul Ponggok also made improvements to the facilities at Umbul Ponggok to comply with government regulations. Improvements made, for example, are repairs to Gazebo facilities, swimming pools, and food stalls. According to the manager of Umbul Ponggok, "Gazebo must be fixed first. For swimming pools, it is clear that it cannot be used because there are still fish, so it must be cleaned first".

The Head of the Village Tourism Division of Ponggok Village, Polanharjo Subdistrict, explained that the Umbul Ponggok tourist attraction is being done in several stages. On the first day of opening, there was a soft opening. The soft opening is used to prepare the new protocol. The admission from the Head of the Village Tourism Division of Ponggok Village is as follows: "The opening day of Umbul Ponggok was marked by the launch of new governance and stricter new health protocol. Our tables are given distance, provided handwashing, mandatory masks, and restrictions on visitors." 
As for the cleanliness of the facilities, all facilities at Umbul Ponggok have been sterilised. Visitors who will swim must also meet special requirements. According to Umbul Ponggok manager: "For those who are going to swim, we have to take a shower first. Even though the water in Ponggok' has permanently been changed regularly, we do not want to take any risks". The number of visitors is also not as much as before the COVID pandemic. The number of visitors has to follow District Government's regulation and will be limited. "Visitors are limited to a minimum of 20 per cent and a maximum of 50 per cent of normal capacity. We also limit the entry; a certain number will enter one hour after completion and then another change".

In the early stages of recovery, the manager of Umbul Ponggok did not target the number of visitors. The target is that, for the time being, all health protocols must be met first. According to the manager of Umbul Ponggok, "Our target is to fulfil the health protocol first. Several visitors are not targeted; the important thing is that when the quota is full, Umbul Ponggok will be closed so that there is still distance and not all visitors are free to enter".

Two water attractions Umbul Ponggok in Polanharjo Subdistrict and Umbul Pelem in Tulung District in Klaten, were said to have had no permits to open during the Coronavirus pandemic. However, then water tourism in Klaten was allowed to open. The Government of Klaten allows water attractions to open from October 26 as long as they comply with the requirements of COVID health protocols.

Adaptation policies with strict health protocols in place also run into challenges. Challenges occur when the holiday season takes place. Two water tour destinations in Klaten opened a door for domestic tourists, but some were positive about the Coronavirus. The Klaten Regency COVID-19 Control Acceleration Task Force wanted to close Umbul Ponggok but finally allowed the Umbul Ponggok tourist attraction to operate. The Klaten Regency Government decided according to the meeting with the Klaten Regent through SE NUMBER: 4/43. 629. 113 concerning the opening of water tourism objects during the pandemic.

The COVID-19 Team and the Regent frequently visit Umbul Ponggok and Umbul Pelem. This team also conducts random swabs to check the safety of tourist attractions. The Health Office delivered the result of the swab, and the village head responded immediately. When a swab test result was confirmed positive, the manager immediately took anticipatory steps. This anticipatory step is by spraying disinfectants and applying sterilisation measures. According to the manager of Umbul Ponggok: "We move quickly. The place was immediately closed and then sprayed, and we conducted independent isolation and rapid tests for those around us". The Village Tourism Division of Ponggok Village, Polanharjo Subdistrict, also confirmed Umbul Ponggok would be closed for three days if visitors are confirmed positive for COVID-19.

This decision was made after a meeting with the village and sub-district task force. For this purpose, disinfectant spraying and rearrangement of facilities are carried out. "Currently, we are sterilising because many visitors are outside the city," said the Umbul Ponggok committee. So far, the managers of Umbul Ponggok and Umbul Pelem have implemented strict protocols. Starting from the outside, you have to wear masks and screen visitors. According to Umbul Ponggok manager: "We have done the health protocol according to the provisions. We also limit the visitors, there are not 100 people who swim, and when it is full we close it".

Following a more open government's policy in Karanganyar, many tourist destinations in Tawangmangu Karanganyar have returned to operations since July 2020. For instances Grojogan Sewu Tawangmangu was only closed when the COVID-19 pandemic began. The leading tourist destination in Tawangmangu Karanganyar was forced to close only in a few months of the COVID-19 pandemic. The reopening of tourist attractions, including in Tawangmangu, must implement the COVID-19 prevention protocol and adjust the particular 
rules applied by each manager. One of the policies that are implemented in Grojogan Sewu is the limitation of visiting time for tourists. However, this only applies when the number of tourists has already exceeded the capacity.

Grojogan Sewu Tawangmangu is known to have a maximum capacity of around 2,000 visitors on a weekday. According to the destination manager, approximately only 600 visitors had visited the Grojogan Sewu. This figure is still far from the number of around 2,000 visitors in Grojogan Sewu Tawangmangu on weekends. The manager claimed that the number of Grojogan Sewu's visits on the reopening of the destination was lower than visits on a typical day before the pandemic. "If you look at the numbers, it seems that there is still no need to apply the duration rule in Grojogan Sewu. Because it is still far from the maximum capacity, but of course, the COVID-19 protocol must be obeyed". The complexity that arises from the Covid19 pandemic shows how local government at the provincial level fail to recognise what Baggio called the "dynamic complex system" of tourism industry10. As a dynamic, complex system, the tourism industry is supported by various actors with numerous factors and activities. All those supports are interdependent, and the relationships are nonlinear.

\section{Conclusion}

Based on the adaptation policies implemented in these two tourist areas, we can argue that adaptation policy during the COVID-19 pandemic depends on the government enforcement as well as the willingness of the destinations' managers, in the case of the Klaten regency, where commitment to enforcing strict health protocols, destination managers are more willing to follow government's regulation. In contrast, the tourism industry in Karanganyar is more reluctant to implement stricter health protocols due to more relaxed enforcement from the government. The findings are in line with Tompkins and Adger's account on adaptation policy. Adaptive capacity can vary between regions and even households. Therefore, it is imperative that each government implement a more strategic and flexible management approach considering the varied characters of communities and individuals.

\section{References}

1. https://covid19.who.int. (2021). WHO Coronavirus Disease (COVID-19) Dashboard. Retrieved Feb 16, 2021, from https://covid19.who.int/

2. https://covid19.go.id. (2021). Peta Sebaran. Retrieved Feb 15, 2021, from https://covid19.go.id/peta-sebaran

3. Creswell, J. W. Research Design: Qualitative, Quantitative and Mixed Method Approaches. SAGE Publications, 203-223 (2007). https://doi.org/10.4135/9781849208956

4. Bakshi, A., Talaei-Khoei, A., \& Ray, P. Adaptive policy framework: A systematic review. Journal of Network and Computer Applications, 36(4), 1261-1271 (2013) https://doi.org/https://doi.org/10.1016/j.jnca.2012.12.007

5. Forino, G., von Meding, J. and Brewer, G. J. 'A conceptual governance framework for climate change adaptation and disaster risk reduction integration', International Journal of Disaster Risk Science, 6(4), pp. 372-384. (2015) doi: 10.1007/s13753-015-0076-z.

6. Ramalingam, B., Wild, L., \& Ferrari, M. Adaptive leadership in the coronavirus response Bridging science, policy and practice (2020) 
7. Shaw, R., Pulhin, J. M. and Pereira, J. J. Climate change adaptation and disaster risk reduction: Overview of issues and challenges, Community, Environment and Disaster Risk Management. Elsevier (2010). doi: 10.1108/S2040-7262(2010)0000004007.

8. Tompkins, E. L. and Adger, W. N. 'Does adaptive management of natural resources enhance resilience to climate change?', Ecology and Society, 9(2) (2004) doi: 10.5751/ES-00667-090210.

9. Tourism Development Master Plan Central Java Province 2012-2027, Rippaprov Central Java 2012-2027, http://disporapar.jatengprov.go.id/content/files/PERDA\%20NO\%2010\%20TAHUN\%2 02012\%20TTG\%20RENCANA\%20INDUK\%20PENGEMBANGAN\%20KEPARIWI SATAAN\%20PROV\%20JATENG\%202012-2027.pdf

10. Baggio, R. (2008). 'Symptoms of complexity in a tourism system'. Tourism Analysis, 13, 1-20 (2008) doi: https://doi.org/10.3727/10835420878454879 